\title{
THE EFFICIENCY OF SELECTION FOR SEED YIELD IN THE FAHL VARIETY OF EGYPTIAN (BERSEEM) CLOVER, Trifolium alexandrinum $\mathrm{L}$. \\ Bakheit, B. R. ${ }^{1}$; M. A. Ali ${ }^{2}$ and A. M. Abo-El-Wafa ${ }^{2}$ \\ 1- Agronomy Department, Fac., of Agric., Assiut Univ., Assiut, Egypt. 2- Agronomy Depart. Fac., of Agric., South Valley Univ., Qena, Egypt.
}

\begin{abstract}
Two cycles of modified mass selection and one cycle of family selection were applied on a population of the Fahl variety of Egyptian clover. In 2003/2004, two hundred plants ( $5 \%$ selection intensity) were selected for seed yield, using the modified mass selection method. Equal seeds from each selected plant were bulked to form each of two selection cycles. Plants selected for $C_{1}$ were also raised as half sib families in 2004/2005 and selection was practiced between and within families for the best 10 families (5\% selection intensity). Seeds of selected half-sib families and both modified mass selection cycles $\mathrm{C}_{1}$ and $\mathrm{C}_{2}$ along with the base population were evaluated for forage and seed yields In 2005/2006 season. Gains realized from $\mathrm{C}_{1}$ and $\mathrm{C}_{2}$ mass selection, respectively were 13.59 and $18.45 \%$ for seed yield, 4.94 and $14.38 \%$ for fresh forage yield, 5.32 and $13.22 \%$ for dry forage yield, 4.05 and $11.56 \%$ for protein yield and 9.12 and $13.21 \%$ for 1000 -seed weight over the base population Gains from family selection as \% of base population were $18.45,8.88,9.91,11.56$ and $3.77 \%$ for these traits in order. Broad sense heritability as based on variance components among half-sib families were 76.82, 76.10, 98.24, 98.73, and 84.34 for seed yield, fresh forage yield, dry forage yield, protein yield, and 1000-seed weight, respectively.

All studied traits were positively correlated but the correlation between seed and forage yields were weak. However, one half-sib family was $30.10 \%$ higher than base population in seed yield, $34.15 \%$ in fresh forage yield, $35.78 \%$ in dry forage yield and $36.42 \%$ in protein yield and $16.35 \%$ heavier in specific seed weight. Results suggest that family selection may be more effective for improving seed yield than modified mass selection.
\end{abstract}

\section{INTRODUCTION}

The single-cut Fahl variety of berseem clover is widely grown in Egypt as a catch crop preceding major summer crops. It has high nutritional value and is very palatable in addition to being highly productive. In Egypt, very little attention has been given to the improvement of seed or forage production potential of berssem compared to other crops. Due to difficult artificial hybridization and high self sterility, selection procedures are mainly used for improving forage and seed yield in this crop.

Selection for seed yield is one of the most important and difficult challenges of plant breeding. Family selection can be used to identify superior genotypes for seed yield in a cultivar development program. The success of any programme of selection to improve seed yield will depend on the genetic variation existing within the initial population, heritability of seed yield, the nature of correlations between seed yield and other traits especially forage yield and the intensity of selection applied. Most of breeders have selected directly for seed yield to improve it. 
Bakheit, B. R. et al.

Koraiem et al., (1980), Omara and Hussein, (1982), Radwan et al., (1983), Bakheit, (1985), Younis et al., (1986) and Mikhiel, (1987) reported that mass selection was effective for improvement of forage yield in multi-cut Egyptian clover varieties. Family selection was more rewarding than mass selection for in improving forage yield in Meskawi Egyptian clover (Omara and Hussein, 1982). Bakheit (1989) found that both modified mass and family selection were effective for improvement of seed yield of the Fahl variety of berseem clover. In contrast, Radwan et al., (1971) stated that visual selection was ineffective for improvement of forage yield in three sets of progenies and the check variety Giza 1 inspite of the wide range in progeny performance and the relatively large heritability estimates for it. No significant response to mass selection for annual forage yield in Miskawi berseem clover was observed by Radwan et al., (1972). Selection applied was not effective for increasing seed yield among maternal half-sib populations of berseem clover (Martiniello and Lannucci, 1998).

The present work describes the results of two different methods of phenotypic directional selection (mass and family selection) for seed yield and related forage yield traits in Fahl Egyptian clover.

\section{MATERIALS AND METHODS}

This investigation was conducted at Qena Agric. Res. Farm, South Valley Univ., during 2003/2004, 2004/2005 and 2005/2006 successive seasons. The base material for this investigation was a Fahl clover population obtained from the Agronomy Dept., Fac. of Agric., Assiut University. During $2003 / 2004$ season, the base population was sown on $17^{\text {th }}$ September in a non-replicated nursery (200 rows $3.15 \mathrm{~m}$ long, $20 \mathrm{~cm}$ apart and $15 \mathrm{~cm}$ between hills within row). After seedling establishment the plants were thinned to one plant per hill. The cultural practices were applied at optimum level for maximum productivity. The best plants in each row plot for seed yield/plant (200 plants $=5 \%$ selection intensity) were selected as parents to produce the next cycle.

\section{Modified mass selection}

In 2004/2005 growing season, equal parts of seeds from each of the 200 selected plants were bulked together to form the first cycle of modified mass selection $\left(C_{1}\right)$. Seeds of $C_{1}$ were sown on 19 th September. The spacing distances, cultural practices, selection procedure and intensity of selection were applied as in the first season and equal parts of seeds from each of the selected plants were bulked together again to form the second cycle $\left(\mathrm{C}_{2}\right)$.

In 2005/2006 growing season, base population and two cycles of mass selection $\left(C_{1}\right.$ and $\left.C_{2}\right)$ were planted on $19^{\text {th }}$ September for estimating the response to selection. A randomized complete block design with six replications, three of them for forage yield traits and the other three replications for seed yield traits was used. Each plot consisted of four square meters with seeds sown by hand in rows, $20 \mathrm{~cm}$ apart, at a seeding rate of 4000 seeds /plot (15 kg/feddan). The culture practices were carried out as recommended. Ninety days from sowing the plots for forage yield were 
clipped by hand sickle. Data were recorded on fresh forage yield/plot and converted into mega gram/hactar. Dry matter percentage was estimated from plot samples of about $300 \mathrm{gm}$ of fresh forage dried at $70 \mathrm{C}^{0}$. The microkjeldahl method as described by A.O.A.C.(1980) was used to determine forage $\mathrm{N}$ content in the dried ground forage Nitrogen percentage was multiplied by 6.25 to obtain crude protein content. At seed maturity plots left for seed production evaluation were harvested and data were recorded on seed yield/plant and were converted to yield/ha.

\section{2- Family selection procedure}

In 2004/2005 season, the seeds of plants selected for $C_{1}$ were established as half-sib families. Each family consisted of 22 spaced plants. The best ten plants in seed yield from the best ten families were selected out (first cycle of family selection $\mathrm{C}_{1}$ ).

In 2005/2006 season, base population and the selected ten families were evaluated in a randomized complete block design with six replications, three of them for forage yield traits and the other three replications for seed yield traits. Each plot consisted of a half square meter $(1 \mathrm{~m} \times 1 / 2 \mathrm{~m})$. Seeds were sown by hand in rows, $20 \mathrm{~cm}$ apart, at a seeding rate of 500 seeds for each replicate equivalent to $15 \mathrm{~kg} / \mathrm{feddan}$. Data were recorded on forage and seed yield traits as outlined for mass selection.

\section{Statistical analysis}

The analysis of variance and the expected mean squares for all studied traits were performed according to Gomez and Gomez (1984). The phenotypic $\left(\delta^{2} p\right)$ and genotypic $\left(\delta^{2} g\right)$ variances were computed as outlined by Al-Jibouri et al., (1958). Phenotypic (P.C.V.) and genotypic (G.C.V.) coefficients of variability were calculated according to Burton (1952). Heritability (broad sense) was calculated as $h^{2}=\delta^{2} g / \delta^{2} p h \quad x \quad 100$. Phenotypic $\left(r_{\mathrm{p} h}\right)$ and genotypic $\left(\mathrm{r}_{\mathrm{g}}\right)$ correlation coefficients were computed from the components of variance and covariance according to Johnson et al., (1955).

The predicted response from selection of the superior $5 \%$ plants in $\mathrm{C}_{1}$ families was estimated as $\mathrm{i} \delta \mathrm{p} \mathrm{h}^{2}$ whereas, the correlated response in trait (y) when selection is applied to seed yield/plant $(x)$ is Cry= i $h_{x} h_{y} r_{g} \delta p_{y}$ according to Falconer (1960), where $\mathrm{CR}_{\mathrm{y}}=$ the correlated response of the trait $(y), i=$ the intensity of selection $=2.063, h_{x}=$ the square root of the heritability of the trait $(x), h_{y}=$ the square root of the heritability of trait $(y), r_{g}=$ the genetic correlation between $(x)$ and $(y)$ traits and $\delta p_{y}=$ the phenotypic standard deviation of trait $(\mathrm{y})$.

\section{RESULTS AND DISCUSSION}

The analysis of variance and mean values of forage and seed yields of the base population, first $\left(\mathrm{C}_{1}\right)$ and second $\left(\mathrm{C}_{2}\right)$ cycles of mass selected populations are illustrated in Tables 1 and 2. No significant differences between the base population and the mass selected populations for forage yields were observed (Table 1). Although, in the first $\left(C_{1}\right)$ and second $\left(C_{2}\right)$ cycles increases were detected of 4.94 and $14.38 \%$ in fresh forage yield, 5.32 and $13.22 \%$ in dry forage yield, 4.05 and $11.56 \%$ in protein yield and 9.12 
and $13.21 \%$ in seed index over the base population, respectively. Comparison of the seed yield of the base and selected $\mathrm{C}_{1}$ populations, shows a significant response to selection. However, no significant differences between the first $\left(\mathrm{C}_{1}\right)$ and second $\left(\mathrm{C}_{2}\right)$ generations of selection were observed. The genetic advance calculated as a percentage of the mean of the base population was 11.79 and $17.14 \%$ after the first $\left(C_{1}\right)$ and second $\left(\mathrm{C}_{2}\right)$ cycles of phenotypic directional selection for seed yield, respectively. But no significant gains were detected for forage yield from mass selection for seed yield. So, after the first cycle of mass selection for seed yield was obtained significant response to selection. Such response could be a reflection of the weak correlation between forage and seed yields. The lack of a more significant response after the first cycle of selection might be due to the inbreeding effect resulting from the high selection intensity. Similar results were obtained by Bakheit (1989), where significant response to mass selection for seed yield was obtained after the first cycle of selection with no significant differences between the first and second cycles of selection. Significant response to mass selection for forage yield after the first cycle of selection was obtained by Omara and Hussein (1982.

Table 1. Mean squares from analysis of variance of forage and seed yields of the base population, first $\left(C_{1}\right)$ and second $\left(C_{2}\right)$ cycles of mass selection of the Fahl variety of berseem clover.

\begin{tabular}{|l|c|c|c|c|c|c|}
\hline \multirow{2}{*}{ S.O.V } & \multirow{2}{*}{ df } & \multicolumn{5}{|c|}{ Mean squares } \\
\cline { 3 - 7 } & & \multicolumn{3}{|c|}{ Forage yields } & \multicolumn{2}{c|}{ Seed yields } \\
\cline { 3 - 7 } & & $\begin{array}{c}\text { Fresh } \\
\text { Meg/ha }\end{array}$ & $\begin{array}{c}\text { Dry } \\
\text { Meg/ha }\end{array}$ & $\begin{array}{c}\text { Protein } \\
\text { yield } \\
\text { Meg/ha }\end{array}$ & $\begin{array}{c}\text { Seed yield } \\
\text { Meg/ha }\end{array}$ & $\begin{array}{c}\text { Seed index } \\
(\mathbf{1 0 0 0 - s e e d ~} \\
\mathbf{g})\end{array}$ \\
\hline Reps & 2 & 3.25 & 0.12 & 0.04 & $0.045^{*}$ & 0.404 \\
\hline Base vs. selection & 1 & 18.81 & 0.82 & 0.04 & $0.053^{*}$ & 0.250 \\
\hline $\mathbf{C}_{1}$ vs. $\mathbf{C}_{\mathbf{2}}$ & 1 & 13.44 & 0.45 & 0.03 & 0.004 & 0.027 \\
\hline Error & 4 & 7.81 & 0.19 & 0.01 & 0.003 & 0.424 \\
\hline
\end{tabular}

** Significant at the $1 \%$ level of probability.

Table 2. Mean forage and seed yields for two cycles of mass selection for seed yield of the Fahl variety of berseem clover grown in the 2005/2006 season.

\begin{tabular}{|l|c|c|c|c|c|}
\hline \multirow{2}{*}{ Generations } & \multicolumn{3}{|c|}{ Forage yields } & \multicolumn{2}{c|}{ Seed yields } \\
\cline { 2 - 6 } & $\begin{array}{c}\text { Fresh } \\
\text { Meg/ha }\end{array}$ & $\begin{array}{c}\text { Dry } \\
\text { Meg/ha }\end{array}$ & $\begin{array}{c}\text { Protein } \\
\text { yield } \\
\text { Meg/ha }\end{array}$ & $\begin{array}{c}\text { Seed yield } \\
\text { Meg/ha }\end{array}$ & $\begin{array}{c}\text { Seed index } \\
(\mathbf{1 0 0 0}-\mathbf{h e e d} \\
\mathbf{g})\end{array}$ \\
\hline Base population & $31.77 \mathrm{a}$ & $6.96 \mathrm{a}$ & $1.73 \mathrm{a}$ & $1.03 \mathrm{a}$ & $3.18 \mathrm{a}$ \\
\hline Cycle 1 & $33.34 \mathrm{a}$ & $7.33 \mathrm{a}$ & $1.80 \mathrm{a}$ & $1.17 \mathrm{~b}$ & $3.47 \mathrm{a}$ \\
\hline Cycle 2 & $36.34 \mathrm{a}$ & $7.88 \mathrm{a}$ & $1.93 \mathrm{a}$ & $1.22 \mathrm{~b}$ & $3.60 \mathrm{a}$ \\
\hline Realized gain \% & & & & & \\
\hline Cycle 1+ $^{+}$ & 4.94 & 5.32 & 4.05 & 13.59 & 9.12 \\
\hline Cycle 2 $^{+}$ & 14.38 & 13.22 & 11.56 & 18.45 & 13.21 \\
\hline
\end{tabular}

Means followed by the same letter in the same column are not significantly different at the $5 \%$ probability level as determined by Duncan's Multiple Range test.

+ Realized gain \%: $\bar{C}_{1}=\bar{C}_{1}-\bar{C}_{0} / \bar{C}_{0} \times 100, \quad \bar{C}_{0}=$ mean base population.

$$
\bar{C}_{2}=\bar{C}_{2}-\bar{C}_{0} / \bar{C}_{0} \times 100
$$


Otherwise, these results for forage yield are in general agreement with those obtained by Ali, (1971), Radwan et al., (1972) and Bakheit, (1985) in Miskawi berseem clover.

\section{2-Family selection}

The analysis of variance of the forage and seed yields of the selected families and their base population are presented in Table 3 . Highly significant differences among families for the traits measured were detected. Highly significant differences between the base population and the selected families for all studied traits, except fresh forage yield and seed index were also observed

Table 4 shows means of forage and seed yields for the base population and the selected families. The average estimated fresh forage yield of the selected families ranged from 23.27 to $42.62 \mathrm{meg} \mathrm{g} \mathrm{ha}^{-1}$ with an average of 34.59 . One family was significantly higher than the base population after one cycle of family selection. With respect to dry forage yield and protein yield, it ranged from 4.93 to $9.45 \mathrm{meg} / \mathrm{ha}$ with an average of 7.65 and from 1.25 to $2.36 \mathrm{meg} / \mathrm{ha}$ with an average of 1.93 , respectively . Furthermore, four families i.e., no. 1, 4, 7 and 8 for dry forage yield and five families (no. 1, 4, 7, 8 and 10) for protein yield were significantly higher than the base population after one cycle of family selection . In addition, seed yield for the ten selected families ranged from 1.02 to $1.36 \mathrm{meg} / \mathrm{ha}$ with an average of $1.22 \mathrm{meg}$, while 1000 -seed weight ranged from 2.80 to $3.70 \mathrm{~g}$ with an average of $3.30 \mathrm{~g}$. Furthermore, six families, namely, no. 1, 4, 7, 8, 9 and 10 for seed yield and two families (no. 1 and 4) for 1000-seed weight were significantly higher than the base population after one cycle of family selection .

It is of interest to note that the overall family mean after one cycle of family selection exceeded the mean of the base population for all studied traits. However, the families which outyielded the base population in seed yield were not higher in fresh forage yield, except family no. 1 which was higher than the base population in both forage and seed yields. These results reflect the weak correlation between forage and seed yields. In addition, family no. 1 could be considered the best selected family which showed $30.10 \%$ increase in seed yield, and was higher than the base population by $34.15 \%$ in fresh forage yield, $35.78 \%$ in dry forage yield, $36.42 \%$ in protein yield and had 16.35 heavier seeds. These results suggest that direct selection for seed yield was effective in improving this population . Bakheit (1989) demonstrated that the families which outyielded the base population in forage yield were not the same families which were superior for seed yield, except only one family. Similar results were obtained by Burton and De Vance (1953) and Cowan (1955) .

Estimates of phenotypic $\left(\delta^{2} p\right)$ and genotypic $\left(\delta^{2} g\right)$ variances, phenotypic (PCV\%) and genotypic (GCV\%) coefficients of variability and heritability $\left(\mathrm{h}^{2}\right)$ for forage and seed yields for the selected families are shown in Table 5 . The phenotypic and genotypic variances expressed as PCV\% and GCV\% were 17.31 and $15.10 \%$ for fresh forage yield, 19.69 and $19.54 \%$ for dry forage yield, 20.51 and $20.40 \%$ for protein yield, 9.35 and $8.06 \%$ for seed yield and 8.73 and $8.02 \%$ for 1000 -seed weight, respectively. These results 
Bakheit, B. R. et al.

revealed sufficient genotypic variability among selected families after one cycle of family selection for seed yield.

Table 3. The analysis of variance of forage and seed yields for the base population and ten selected families of the Fahl variety of berseem clover grown in the 2005/2006 season.

\begin{tabular}{|l|c|c|c|c|c|c|}
\hline \multirow{2}{*}{ S.O.V } & \multirow{2}{*}{ df } & \multicolumn{5}{c|}{ Mean squares } \\
\cline { 3 - 7 } & & \multicolumn{3}{|c|}{ Forage yields } & \multicolumn{2}{c|}{ Seed yields } \\
\cline { 3 - 7 } & & $\begin{array}{c}\text { Fresh } \\
\text { Meg/ha }\end{array}$ & $\begin{array}{c}\text { Dry } \\
\text { Meg/ha }\end{array}$ & $\begin{array}{c}\text { Protein } \\
\text { Meg/ha }\end{array}$ & $\begin{array}{c}\text { Seed yield } \\
\text { Meg/ha }\end{array}$ & $\begin{array}{c}\text { Seed index } \\
(\mathbf{1 0 0 0}-\mathbf{s e e d})\end{array}$ \\
\hline Reps & $\mathbf{2}$ & 15.01 & 0.53 & 0.010 & 0.01 & 0.05 \\
\hline Families & $\mathbf{1 0}$ & $99.00^{* *}$ & $6.26^{* *}$ & $0.434^{* *}$ & $0.045^{* *}$ & $0.23^{* *}$ \\
\hline Base vs. selected fam. & $\mathbf{1}$ & 21.68 & $1.31^{* *}$ & $0.110^{* *}$ & $0.090^{* *}$ & 0.04 \\
\hline Between families & $\mathbf{9}$ & $107.59^{* *}$ & $6.81^{* *}$ & $0.470^{* *}$ & $0.039^{* *}$ & $0.25^{* *}$ \\
\hline Error & $\mathbf{2 0}$ & 25.72 & 0.11 & 0.005 & 0.010 & 0.04 \\
\hline
\end{tabular}

** Significant at the $1 \%$ level of probability.

Table 4. Means of forage and seed yields for the base population and the ten selected families of the Fahl variety of berseem clover.

\begin{tabular}{|c|c|c|c|c|c|}
\hline \multirow{2}{*}{ Family } & \multicolumn{3}{|c|}{ Forage yields } & \multicolumn{2}{c|}{ Seed yields } \\
\cline { 2 - 5 } & $\begin{array}{c}\text { Fresh } \\
\text { Meg/ha }\end{array}$ & $\begin{array}{c}\text { Dry } \\
\text { Meg/ha }\end{array}$ & $\begin{array}{c}\text { Protein } \\
\text { Meg/ha }\end{array}$ & $\begin{array}{c}\text { Seed yield } \\
\text { Meg/ha }\end{array}$ & $\begin{array}{c}\text { Seed index } \\
(\mathbf{1 0 0 0}-\mathbf{h e e d})\end{array}$ \\
\hline $\mathbf{1}$ & $42.62 \mathrm{e}$ & $9.45 \mathrm{f}$ & $2.36 \mathrm{~g}$ & $1.34 \mathrm{~d}$ & $3.70 \mathrm{e}$ \\
\hline $\mathbf{2}$ & $30.30 \mathrm{abc}$ & $6.66 \mathrm{bc}$ & $1.64 \mathrm{bc}$ & $1.02 \mathrm{a}$ & $3.50 \mathrm{cde}$ \\
\hline $\mathbf{3}$ & $31.95 \mathrm{abcd}$ & $6.83 \mathrm{~cd}$ & $1.67 \mathrm{c}$ & $1.07 \mathrm{a}$ & $2.90 \mathrm{ab}$ \\
\hline $\mathbf{4}$ & $40.45 \mathrm{de}$ & $9.40 \mathrm{f}$ & $2.34 \mathrm{~g}$ & $1.36 \mathrm{~d}$ & $3.60 \mathrm{de}$ \\
\hline $\mathbf{5}$ & $29.35 \mathrm{ab}$ & $6.21 \mathrm{~b}$ & $1.54 \mathrm{~b}$ & $1.20 \mathrm{abcd}$ & $3.20 \mathrm{bc}$ \\
\hline $\mathbf{6}$ & $33.57 \mathrm{bcde}$ & $7.35 \mathrm{~d}$ & $1.82 \mathrm{~d}$ & $1.13 \mathrm{abc}$ & $3.30 \mathrm{~cd}$ \\
\hline $\mathbf{7}$ & $37.64 \mathrm{bcde}$ & $8.45 \mathrm{e}$ & $2.19 \mathrm{e}$ & $1.24 \mathrm{bcd}$ & $3.40 \mathrm{cde}$ \\
\hline $\mathbf{8}$ & $37.00 \mathrm{bcde}$ & $8.21 \mathrm{e}$ & $2.20 \mathrm{ef}$ & $1.24 \mathrm{bcd}$ & $2.80 \mathrm{a}$ \\
\hline $\mathbf{9}$ & $23.27 \mathrm{a}$ & $4.93 \mathrm{a}$ & $1.25 \mathrm{a}$ & $1.27 \mathrm{~cd}$ & $3.40 \mathrm{cde}$ \\
\hline $\mathbf{1 0}$ & $39.77 \mathrm{cde}$ & $9.04 \mathrm{~cd}$ & $2.31 \mathrm{fg}$ & $1.31 \mathrm{~d}$ & $3.20 \mathrm{bc}$ \\
\hline Base population & $31.77 \mathrm{abcd}$ & $6.96 \mathrm{bcd}$ & $1.73 \mathrm{~cd}$ & $1.03 \mathrm{a}$ & $3.18 \mathrm{bc}$ \\
\hline Selec. fam. mean & 34.59 & 7.65 & 1.93 & 1.22 & 3.30 \\
\hline
\end{tabular}

Means followed by the same letter in the same column are not significantly different at the $5 \%$ probability level as determined by Duncan's Multiple Range test.

Broad-sense heritability (Table 5) was high in magnitude for dry forage yield (98.24\%), protein yield (98.73\%) and 1000-seed weight $(84.34 \%)$, indicating that the environmental effects were small compared to the genetic effects. However, heritability of fresh forage yield and seed yield was smaller than dry yield suggesting more environmental influences on fresh yield and seed yield. Similar results were reported by Bakheit (1989).

Expected and realized gains from direct selection for seed yield and correlated responses in forage and protein yields and 1000-seed weight are presented in Table 5. The results indicated that after one cycle of family selection, the realized gain for seed yield reached $18.45 \%$ from the base population. Likewise, the expected gain from selection based on the superior $5 \%$ plants in $\mathrm{C}_{1}$ family selection was $17.48 \%$. Furthermore, favourable increase in fresh forage yield $(8.88 \%)$, dry forage yield $(9.91 \%)$, protein yield $(11.56 \%)$ and $(3.77 \%)$ in 1000-seed weight were obtained (Table 5). Comparison of the expected and realized gain from selection shows a quite 
good agreement between expected and realized gain in seed yield and seed index. But for forage yields, the realized response was higher than the expected one. These results are in line with those reported by Bakheit (1989).

Table 5. Phenotypic variance $\left(\delta^{2} p\right)$ and genotypic $\left(\delta^{2} g\right)$ variances, phenotypic (PCV\%) and genotypic (GCV\%) coefficients of variability, heritability\% $\left(h^{2}\right)$ and realized response for various characters in ten selected families of the Fahl variety of berseem clover .

\begin{tabular}{|c|c|c|c|c|c|}
\hline \multirow[b]{2}{*}{ Estimate } & \multicolumn{3}{|c|}{ Forage yields } & \multicolumn{2}{|c|}{$\begin{array}{l}\text { Seed yields } \\
\end{array}$} \\
\hline & $\begin{array}{c}\text { Fresh } \\
\text { Meg/ha }\end{array}$ & $\begin{array}{c}\text { Dry } \\
\text { Meg/ha }\end{array}$ & $\begin{array}{l}\text { Protein } \\
\text { Meg/ha }\end{array}$ & $\begin{array}{l}\text { Seed yield } \\
\mathrm{Meg} / \mathrm{ha}\end{array}$ & $\begin{array}{c}\text { Seed index } \\
(1000 \text {-seedg) }\end{array}$ \\
\hline$\delta^{2} p$ & 35.86 & 2.27 & 0.157 & 0.013 & 0.083 \\
\hline$\delta^{2} g$ & 27.29 & 2.23 & 0.155 & 0.010 & 0.070 \\
\hline PCV (\%) & 17.31 & 19.69 & 20.51 & 9.35 & 8.73 \\
\hline GCV (\%) & 15.10 & 19.54 & 20.40 & 8.06 & 8.02 \\
\hline $\mathrm{h}^{2} \quad(\%)$ & 76.10 & 98.24 & 98.73 & 76.82 & 84.34 \\
\hline \multicolumn{6}{|l|}{ Expected response: } \\
\hline \begin{tabular}{|r|} 
unit \\
\end{tabular} & 1.89 & 0.55 & 0.17 & 0.18 & 0.11 \\
\hline$\%$ of base population & 5.95 & 7.90 & 9.83 & 17.48 & 3.46 \\
\hline \multicolumn{6}{|l|}{ Realized response: } \\
\hline \begin{tabular}{|r|} 
unit \\
\end{tabular} & 2.82 & 0.69 & 0.20 & 0.19 & 0.12 \\
\hline$\%$ of base population & 8.88 & 9.91 & 11.56 & 18.45 & 3.77 \\
\hline
\end{tabular}

Realized gain was calculated as $\bar{C}_{1}=\bar{C}_{1}-\bar{C}_{0} / \bar{C}_{0} \times 100, \quad \bar{C}_{0}=$ mean base population.

The results of phenotypic $\left(r_{p} h\right)$ and genotypic $\left(r_{g}\right)$ correlations between each pair of the five traits (Table 6) showed that the genotypic correlation coefficients between traits related to forage yields (fresh, dry and protein yields) were higher than their corresponding phenotypic correlations. Also, high genotypic correlations suggested that there was inherent relationship between the traits in question. On the contrary, results for correlations between seed and forage yields indicated a weak positive correlation between seed yield and forage yield (0.200). These results confirmed those obtained from the analysis of variance of Table 3 . These results are in line with those obtained by Schaaf et al., (1962), El-Hattab et al., (1969) and Bakheit (1989) .

Table 6. Phenotypic (above) and genotypic (below diagonal) correlation coefficients among pairs of traits of ten selected families of the Fahl variety of berseem clover.

\begin{tabular}{|l|c|c|c|c|c|}
\hline \multirow{2}{*}{\multicolumn{1}{|c|}{ Traits }} & \multicolumn{3}{c|}{ Forage yields } & \multicolumn{2}{c|}{ Seed yields } \\
\cline { 2 - 6 } & $\begin{array}{c}\text { Fresh } \\
\text { Meg/ha }\end{array}$ & $\begin{array}{c}\text { Dry } \\
\text { Meg/ha }\end{array}$ & $\begin{array}{c}\text { Protein } \\
\text { Meg/ha }\end{array}$ & $\begin{array}{c}\text { Seed yield } \\
\text { Meg/ha }\end{array}$ & $\begin{array}{c}\text { Seed index } \\
\text { (1000-seedg) }\end{array}$ \\
\hline Fresh forage yield Meg/ha & - & 0.726 & 0.558 & 0.430 & 0.068 \\
\hline Dry forage yield Meg/ha & 1.120 & - & 0.784 & 0.501 & 0.158 \\
\hline Protein yield Meg/ha & 1.010 & 1.07 & - & 0.597 & 0.184 \\
\hline Seed yield Meg/ha & 0.200 & 0.202 & 0.232 & - & 0.163 \\
\hline $\mathbf{1 0 0 0 - s e e d ~ w e i g h t ~ g ~}$ & 0.176 & 0.200 & 0.199 & 0.221 & - \\
\hline
\end{tabular}




\section{REFERENCES}

Ali, F. M. 1971. The effect of mass selection on forage yield and related traits in berseem clover (Trifolium alexandrinum L.). M.Sc. Thesis, Faculty of Agric. Cairo Univ., Giza, Egypt.

Al-Jibouri, H. A., P. A. Miller and H. F. Robinson. 1958. Genotypic and environmental variances and covariances in an upland cotton cross of interspecific origin . Agron. J. 50: 633-636.

A. O. A. C. 1980. Official Methods of Analysis" Association of Official Analytical Chemists. $13^{\text {th }}$ ed. A. O. A. C., Washington D. C.

Bakheit, B. R. 1985. Effect of mass and family selection on productivity of Egyptian clover (Trifolium alexandrinum L.). Assiut J. of Agric. Sci., 16: 35-46.

Bakheit, B. R. 1989. Selection for seed yield in Egyptian clover (Trifolium alexandrinum L.) C. V. Fahl. Plant Breeding 103: 278-285.

Burton, G. W. 1952. Quantitative inheritance in grasses. Proc. $6^{\text {th }}$ Int. Grassland Congr. 1: 277-283.

Burton, G. W. and E. H. De Vance. (1953). Estimating heritability in tall fescue (Festuca Arnudinacea) from replicated clonal material. Agronomy J. 45: 478-481.

Cowan, J. R. 1955. Rep. 9th West. Gass Breeders Work Planning Conf. (Cited after proceeding of the $X$ International Grassland Congress, 1966. The problem of breeding for improved seed yields in Grasses 749-754).

El-Hattab, H., M. S. Radwan and A. M. Rammah. 1969. Phenotypic variability and interrelations among characters of berseem (Trifolium alexandrinum L.). Proc. Sixth Arab. Sci. Congress Damscus : 209-219.

Gomez, K. A. and A. A. Gomez, 1984. Statistical Procedures for Agricultural Research . John Wiley \& Sons . Inc., New York, USA .

Johnson, H. W., H. F. Robinson and R.E. Comstock. 1955. Estimates of genetic and environmental variability in soybeans. Agron. J. 47: 314318.

Koraiem, Y. S., M. M. Habib, M. M. El-Rouby and M. T. H. Hassan. 1980. Selection in berseem clover (Trifolium alexandrinum L.). Alex. J. Agric. Res. 28: 455-462.

Martiniello, P. and A. Lannucci. 1998. Genetic variability in herbage and seed yield in selected half-sib families of berseem clover, Trifolium alexandrinum L. Plant Breeding. 117: 559-562.

Mikhiel, G. S. 1987. Studies on forage crops improvements. Ph.D. Thesis, Faculty of Agriculture, Alexandria Univ., Egypt.

Omara, M. K., and M. Y. Hussein. 1982. Selection for productivity of green material in berseem clover (Trifolium alexandrinum L.). Assiut J. of Agric. Sci., 13: 105-116.

Radwan, M. S., N. I. Farid, A. M. Rammah and A. Mostafa. 1971. Progeny testing in berseem (Egyptian clover), Trifolium alexandrinum L. Z. Pflanzenzuchtung 66: 235-239. 
Radwan, M. S., F. M. Ali, S. Galal, Jr. and H. El-Hattab. 1972. The influence of mass selection on berseem clover, Trifolium alexandrinum $\mathrm{L}$. Mesopotamia J. Agric. 7: 29-35.

Radwan, M. S., R. Shabana, A. M. Rammah and M. A. El-Nehrawi. 1983. Variability and combining ability estimates in farmers seed lots of Egyptian clover (Trifolium alexandrinum L.). $1^{\text {st }}$ Hon. Con. Agric. Bot. Sci. April, 1983.

Schaaf, H. M., G. A. Rogler and R. J. Lorenz. 1962. Importance of variations in forage yield, seed yield and seed weight to the improvement of crested wheatgrass. Crop Sci., 2: 67-71.

Younis, A. A., A. M. Rammah and F. M. Ali. 1986. Efficiency of visual selection under competitive conditions in five populations of berseem clover (Trifolium alexandrinum L.) on forage yield. Egyptian Society, of Crop Science, Proceedings of the Second Conference of Agronomy, 2: 873-885.

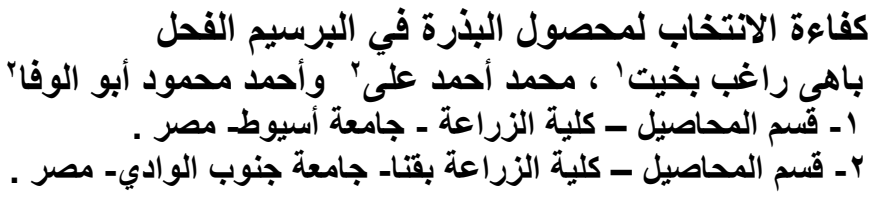

أجريت دورتان من الانتخاب الأجمالى المحور ودورة واحدة من الانتخاب العـائلي لار اسـة فعالية

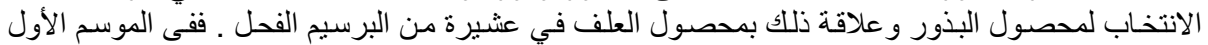

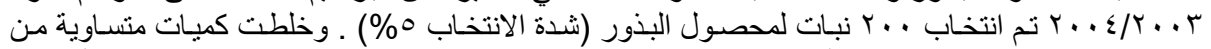

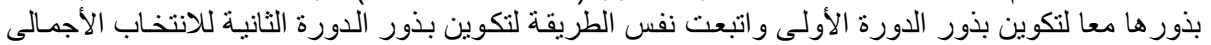

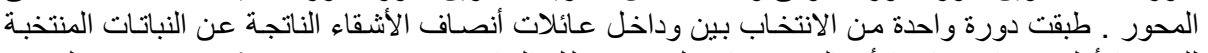

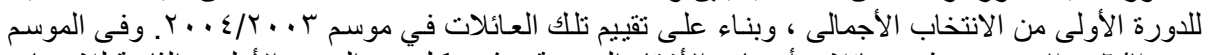

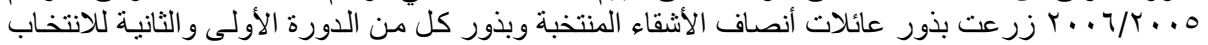

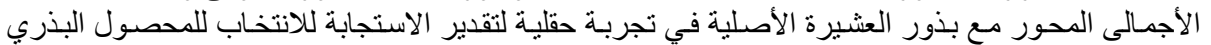

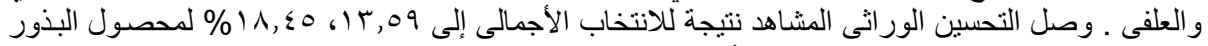

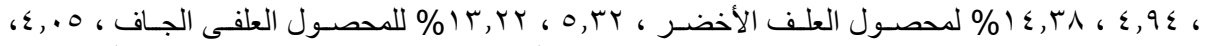

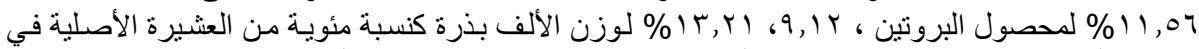

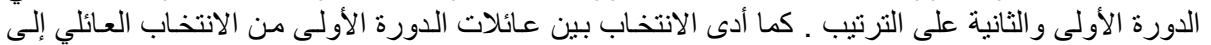

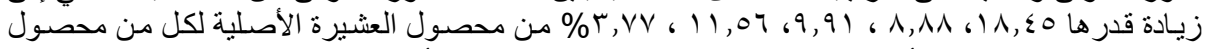

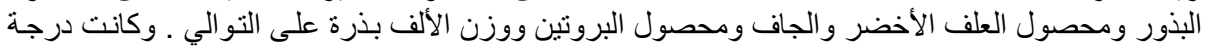

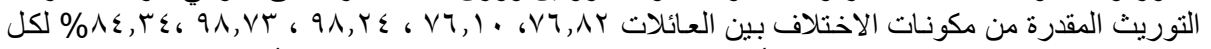

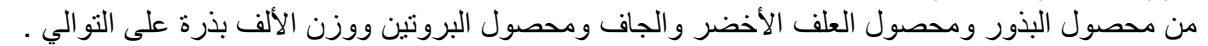

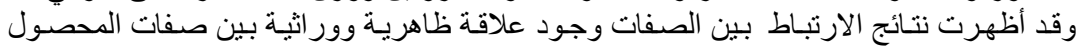

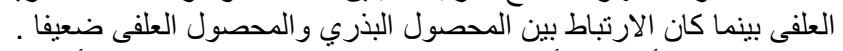

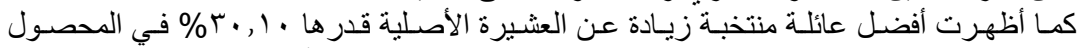

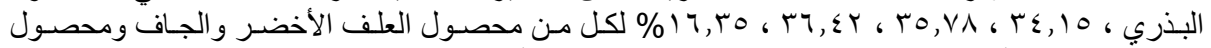
البروتين ووزن الألف بذرة على التوالي ـ وهذه النتائج توضح أن الانتخاب العـائلي المباشر للمحصسول البذري كان فعالا في تحسين هذه العشيرة . الافئ 